\title{
Event Study on the Crash of Airasia Plane: A Study on Travel and Leisure Companies Listed at Malaysian Stock Market*)
}

\author{
Tatang Ary Gumanti ${ }^{1 *}$, Enni Savitri ${ }^{2}$, Nurul Wahidatun Nisa ${ }^{1}$, Elok Sri Utami ${ }^{1}$ \\ ${ }^{1}$ Faculty of Economics and Business Universitas Jember, \\ Jln. Kalimantan 37, Jember 68121, INDONESIA \\ ${ }^{2}$ Faculty of Economics Universitas Riau, Pekanbaru, INDONESIA \\ E-mail: tatangag@unej.ac.id; enisavitri@gmail.com; wahidanisa18@gmail.com; elok_utami@yahoo.co.id \\ *Corresponding author
}

\begin{abstract}
This study analyzes the Malaysian stock market reaction in the event of the crash of AirAsia plane on 28 December 2014. The analysis is focused on the travel and leisure industry as the crash would affect more on this type of industry. A total of 15 companies met the selection criteria. The study uses the event study standard procedures in testing the proposed hypotheses. Results show that abnormal returns after the crash tend to decrease, yet no significant abnormal returns were found in the period before and after the event. Median abnormal return after the event is significantly higher than before the event at the traditional level. Another finding shows that there is no significant difference in trading volume activity between before and after the event.
\end{abstract}

Keywords: Abnormal return; event study; AirAsia plane crash.

*) The first draft of this paper was presented at the $4^{\text {th }}$ Gadjah Mada International Conference on Economics and Business (GAMAICEB) 2016, Yogyakarta 25-27 November 2016. The authors benefit some comments from the Conference participants.

\section{INTRODUCTION}

An airplane crash may have direct consequences not only for the company involved in the disaster but also for other companies in the related industry. For the airline company, three possible impacts may be resulted [4]. These include the damage of the aircraft, human victims and goodwill of the company, and the decline of the passengers that will, in turn, affect the company's market share. These all will bring about to the decrease in income and profits of the company, which in turn would change the company's value.

Many studies have been directed to examine the effect of airplane disaster on the stock price of the aircraft companies. These include [8], [9]), and [5]. The focus of these studies is on the stock prices of the aircraft companies and their competitor as well the aircraft manufacturers. Most of the existing studies document significant price drop in the period after the events.

There are four tragic and terrific airline disasters in 2014 ([19]; [16]). The first accident was the Twin Otter of Nepal Airlines which crashed on February, 16 in Dhikura, about $74 \mathrm{~km}$ from Pokhara, Nepal. The second was happening on March, eight where the Malaysia Airlines flight number MH 370 serving flight from Kuala Lumpur to Beijing has lost contact after one hour of takeoff. The third accident involved Malaysia Airlines airplane flight number MH 17 which was reported being shot down near Hrabove. Donetsk Oblast, Ukraine. The fourth was the crash of AirAsia QZ8501 on 28 December 2014 on its regular route from Surabaya to Singapore. The plane was lost contact with the sky of Indonesia.

The AirAsia plane disaster took place at the end of the year 2014 of which it was just after Christmas and approached New Year holiday. During that time the number of passengers increased sharply, and the travel and leisure industry has been expecting high demand for services. The accident could be believed to affect the intention of people to spend their holiday which in turn would change the industry and their stock values.

AirAsia is considered to be the largest airline in Malaysia in terms of fleet size and destination and is the most significant low-cost airline in terms of passengers and jet fleet in Asia. It became a public company in November 2004. We posit that as the greatest low-cost airline as well the largest airline in Malaysia with many subsidiaries in other Asian countries, the effect of the airline crash 
would affect the image and confident of passengers that will, in turn, affect the related companies in the same industry.

The current study focuses on the impact of the AirAsia plane crash on the stock prices of companies in the industry that would be directly or indirectly affected by accident. This industry is the Travel and Leisure Companies of the Kuala Lumpur Stock Exchange. The event is the crash of AirAsia plane on 28 December 2014 on its way from Surabaya to Singapore.

Results of analysis using standard event study methodology reveal that the companies in the Travel and Leisure industry are not affected by the crash. In this case, although the abnormal returns tend be decreasing in the period after the crash, the decrease is not significantly different compared to the period prior to the event. In addition, the current study does not find a significant difference in terms of trading volume activity of the stocks of the companies examined.

The paper is organized as follows. Section two presents a brief literature review and previous studies including the hypotheses presentation. Part three explains the research methods. The part is followed by the presentation of results and discussion. The final section summarizes the paper.

\section{LITERATURE REVIEWS AND HYPOTHESES DEVELOPMENT}

According to [11], an event study allows measuring the impact of a specific event on the market value of a particular company or the companies in a particular segment. [15] asserts that there are typically two purposes of the event studies. First, it tests for the existence of an "information effect" on the firm's value. Second, it identifies factors that explain changes in the value of a firm just after the event date. Despite being widely used in empirical works, the event study method is believed to the certain extent to be insufficient in understanding their consistency and power where applied in rational expectations setting.

Given its nature, aviation accidents are rare and they are classified as an unexpected event. The occurrence of the event is believed to depress the stock prices of the companies involved ([14]; [9]). There have been many studies directed to test whether an aviation accident has led to the decline of the market value of the airline companies, the manufacturers, or the industry related to the airline businesses.

Findings on the effect of airline disasters on stock prices are still mixed. For example, [4] examine the impact of airplane crashes on the value of the airline's stocks. They study a sample of
57 crashes during the period 1965-1984. Their findings reveal a significant negative reaction on the value of the airlines only the most severe accidents with the most significant number of fatalities. However, these negative abnormal returns reactions restored the days after the crash.

A relatively similar study was performed by [1]. They examine a sample of 49 crashes with at least ten fatalities during the period 1962-1985. A negative but insignificant abnormal stock return was found on the companies but not for the industry and the manufacturers. The abnormal returns do not continue the days after the crash.

[10] study the impact of aviation disasters. They examine the short-term and long-term performance of airlines and airplane manufacturers. The sample consists of 138 airplane crashes between 1962 and 2003. They document significant stock price declines both for the carriers and the manufacturers following the disasters. The declines in the stock prices remain for the airlines in the short term, but they diminish in the long run.

[9] examine the effect of aviation disasters on stock prices and find that the stock price of the company associated with the accident suffers significant negative impact compared to the average market price. They also see average losses of US\$ 60 billion for each air disaster and note empirical evidence of increased volatility after airplane crashes. They document that price reversal occurs in two days after the crash and volatility increases after aviation disasters.

[3] investigate whether the market overreacts to the news of aviation disasters, by predicting the decline in the stock prices of the companies associated with the accident (manufacturer and airline). They perform an event study by considering all the aviation accidents from 1998 to 2009 with more than ten fatalities. They examine the performance of the stock prices in the days after the event of the respective airlines and aircraft manufacturers. The findings suggest that investor could use the accident as the trading strategy given there are significant abnormal returns in the period after the crash both for the manufacturer and the airline stocks.

[8] examine the impact of aviation tragedy in the United States on the market value of the crash airlines and their rival airlines for period 19502009. They find that the influence of an aviation tragedy the after the crash on the stock value of the airlines, both crash, and non-crash, is almost related to the level of fatality involved in the tragedy. They also document that air crash tragedy with the higher number of fatality, i.e., many people died in an accident - is associated with the more substantial negative impact on the market 
value of the crash airlines over the post-crash period. Nevertheless, the market value of the noncrash airlines takes advantage of such tragedy when the fatality is small.

Previous studies show that the findings of stock market reaction to the airline disasters are mixed. For example, [4], [10], and [8] report negative reaction after the crash, but [1] and [3] do not find a significant negative response on days after the crash. The current study is different compared to previous ones in a way that it examines the impact of aircraft disaster on other companies in the industry that would be affected by accident.

Event studies have been performed in Malaysian as well Indonesian stock exchanges using various events. It seems that capital market participants do not always consider that specific event to be material enough to affect their trading strategies. For example, [13] do not find the significant reaction of Malaysian stock market calendar effect for the Eid al-Fitr among firms included in the Syariah Index for the period from 2000 to 2003. [12] document the significant negative abnormal return on the event date of Indonesian legislative election. Handayani (2009) reports that the announcement of fuel price increases does not have a substantial effect on the stock prices. [6] find that the publication of the Central Bank of Indonesia rates (BI-rate) increases in 2013 have significant abnormal returns in the period prior to the announcement, on the announcement date, and after the announcement of on stock prices of the banking sector at Indonesian Stock Exchange.

Previous studies also document that there is a significant difference in the trading volume activities surrounding the event. This difference is caused by the changes in the investors' expectation concerning the event. More investor is taking trading activities as their anticipation following the incident. Given this evidence, the current study also examines the possible trading volume difference after the AirAsia plane crash.

Previous studies examine price changes along with trading volume when analyzing the effect of an event [18]. It is argued that particular event does trigger not only the price of the stocks but also the volume of stocks being traded. In addition, the literature also shows that there is a positive correlation between stock returns and trading volume (See for example [7]; [17]). In this study, the inclusion of trading volume activity is motivated by the argument that if the event is material, then it would affect the trading strategy of the market participants. So, when an event is considered to be influential, the volume of stocks will also be changed.
The arguments mentioned above have made it clear that there have been many studies examining the effect of airplane disasters on the stock prices of the airline companies, the manufacturers, and the industry. These studies seem to have contradicting results where not all of the events have been associated with significant negative abnormal returns in the days after the crash. This study tries to contribute to the literature by giving complementary evidence on the possibility of confirming or denying the existence of a significant negative influence on the value of companies in the industry presumably to be most affected by the airplane crash.

Following the theoretical review and empirical studies, this study will test four hypotheses, which are as follows.

H1: There is the significant abnormal return of stocks of travel and leisure industry listed at Kuala Lumpur Stock Exchange before the crash of AirAsia plane.

H2: There is a significant abnormal return of stocks of travel and leisure industry listed at Kuala Lumpur Stock Exchange after the crash of AirAsia plane.

H3: There is a significant difference of abnormal returns of stocks of travel and leisure industry listed at Kuala Lumpur Stock Exchange between before and after the crash of AirAsia plane.

H4: There is a significant difference of Trading Volume Activity of stocks of travel and leisure industry listed at Kuala Lumpur Stock Exchange between before and after the crash of AirAsia plane.

\section{METHODS}

\section{Sample and Methods of Analysis}

The population of this study is all companies in the Travel and Leisure industry listed at the Kuala Lumpur stock exchange. There are 24 companies in the industry. The sample consists of 15 companies of actively traded stocks.

Abnormal return is measured as the difference between actual return and expected return, expressed as the following equation.

$$
\mathrm{AR}_{i t}=\mathrm{R}_{i t}-\mathrm{E}\left(\mathrm{R}_{i t}\right)
$$

where $\mathrm{AR}_{i t}$ is the abnormal return of stock $i$ on period $t, \mathrm{R}_{i t}$ is the actual return of stock $i$ on period $t$, and $\mathrm{E}\left(\mathrm{R}_{i t}\right)$ is the expected return of stock $i$ on period $t$.

Actual return $\left(\mathrm{R}_{i t}\right)$ is calculated using the following formula: 


$$
\mathrm{R}_{i t}=\operatorname{Ln}\left(\mathrm{P}_{t} / \mathrm{P}_{t-1}\right)
$$

where $\mathrm{P}_{t}$ is the price of stock $i$ on period $t$, and $\mathrm{P}_{t-1}$ is the price of stock $i$ on period $t-1$.

The expected return is estimated using the single index model that can be expressed as follows:

$$
\mathrm{E}\left(\mathrm{R}_{i t}\right)=\mathrm{a}_{i}+B_{i} \mathrm{E}\left(\mathrm{Rm}_{t}\right)
$$

where $\alpha_{i}$ is the alpha factor, $B_{i}$ is the sensitivity of returns of stock $i$ over market movements (also known as the beta of stock $i$ ), $\mathrm{R}_{m t}$ is the market return on period $t$ and is calculated as follows:

$$
\mathrm{R}_{m t}=\mathrm{Ln}\left(\mathrm{CI}_{t} / \mathrm{CI}_{t-1}\right)
$$

where CI is the composite index of the corresponding period.

Trading volume acivity is measured using the following equation:

$$
\operatorname{TVA}_{i, t}=\left(\operatorname{TST}_{i, t} / \operatorname{TOS}_{i, t}\right)
$$

where TVA $\mathrm{TV}_{i t}$ is Trading Volume Activity of stock $i$ at time $t, \mathrm{TST}_{i, t}$ is Total Stock Traded of stock $i$ at time $t$, TOS $_{i, t}$ is Total Outstanding Stocks of stock $i$ at time $t$.

This study uses One Sample t-test, pair samples t-test, Wilcoxon One Sample test, and two pair samples Wilcoxon test. The tests were performed for five days before and five days after the event (five windows period). The use of t-test or Wilcoxon test depends on the distribution of the data. If the data are normally distributed, the test will be based on t-test, and if the distribution of data is not-normal, the Wilcoxon test will be performed.

\section{RESULTS AND DISCUSSION}

\section{Descriptive Data}

Table1 presents the descriptive statistics of abnormal returns. As shown in Table 1, the behavior of mean abnormal returns after the event does not indicate negative returns except for days two and three. The average abnormal returns on day one, day four and day five are positive. These findings are impressive given the fact that only in two out of five days after the event where the abnormal returns are negative, which may lead us to question of the real impact of the AirAsia plane crash on the companies' abnormal returns. Average trading volume activity after the event is lower compared to the period before the event, 0.0173 compared to 0.0217 , respectively. This could be an indication of increase stock trading activity. This also means that investors increase their trading activities after the event.

To test for data normality, Shapiro-Wilk test is used in this study. Table 4 present the results of data normality tests for both before and after the event. For the period before the event, most of the data are not normally distributed, of which the distribution of the data of four out of five days of analysis are not normal. But after the event, the distribution of data is normal, of which the data in three out of five days are normally distributed. Not

\begin{tabular}{|c|c|c|c|c|c|}
\hline Day & Mean & Median & Minimum & Maximum & $\begin{array}{l}\text { Standard } \\
\text { Deviation }\end{array}$ \\
\hline \multicolumn{6}{|l|}{ Panel A. Before the event } \\
\hline-5 & -0.0209 & -0.0066 & -0.1735 & 0.0217 & 0.0452 \\
\hline-4 & 0.0135 & 0.0000 & -0.0429 & 0.2008 & 0.0554 \\
\hline-3 & -0.0112 & 0.0000 & -0.0690 & 0.0130 & 0.0278 \\
\hline-2 & 0.0001 & 0.0000 & -0.0821 & 0.0869 & 0.0424 \\
\hline-1 & -0.0074 & 0.0000 & 0.0812 & 0.1707 & 0.0565 \\
\hline$-5--1$ & -0.0038 & 0.0000 & -0.1735 & 0.2008 & 0.0468 \\
\hline \multicolumn{6}{|l|}{ Panel B. Before the event } \\
\hline+1 & 0.0002 & 0.0000 & -0.0601 & 0.0741 & 0.0284 \\
\hline+2 & -0.0043 & 0.0003 & -0.0741 & 0.0640 & 0.0336 \\
\hline+3 & -0.0155 & -0.0044 & -0.1135 & 0.0328 & 0.0376 \\
\hline+4 & 0.0297 & 0.0030 & -0.0160 & 0.3401 & 0.0882 \\
\hline+5 & 0.0093 & 0.0056 & -0.0223 & 0.0296 & 0.0141 \\
\hline$+1-+5$ & 0.0038 & 0.0023 & -0.1135 & 0.3401 & 0.0487 \\
\hline \multicolumn{6}{|c|}{ Panel C. Trading Volume Activity } \\
\hline Pre-event & 0.0173 & 0.0015 & 0.0000 & 0.2648 & 0.0499 \\
\hline Post-event & 0.0217 & 0.0025 & 0.0001 & 0.4308 & 0.0738 \\
\hline
\end{tabular}
reported in the table, the distribution of data of trading volume activity is not normal.

Table 1. Descriptive Statistics of Stock Abnormal Return 
Table 4. Results of Data Normality Tests

\begin{tabular}{cccc}
\hline Period & Z Statistic & Sig & Data Distribution \\
\hline \multicolumn{4}{c}{ Panel A. Days before the event } \\
\hline-5 & 0.626 & 0.000 & Not normal \\
-4 & 0.622 & 0.000 & Not normal \\
-3 & 0.729 & 0.001 & Not normal \\
-2 & 0.960 & 0.697 & Normal \\
-1 & 0.795 & 0.003 & Not normal \\
$-5--1$ & 0.793 & 0.000 & Not normal \\
\hline \multicolumn{5}{l}{ Panel B. Days after the event } & \\
\hline+1 & 0.902 & 0.103 & Normal \\
+2 & 0.903 & 0.105 & Normal \\
+3 & 0.851 & 0.018 & Not normal \\
+4 & 0.464 & 0.000 & Not normal \\
+5 & 0.909 & 0.129 & Normal \\
$+1-+5$ & 0.596 & 0.000 & Not normal \\
\hline \multicolumn{5}{r}{}
\end{tabular}

\section{Results of Hypotheses Test}

Table 5 summarizes the results of the test of hypotheses one and two. In the period prior to the event, significant abnormal returns are found in the only day minus five $(-5)(\mathrm{Z}=-0.012, \mathrm{p}=0.031)$. While, for the period after the event, the study finds that only on the day plus five $(+5)$ where the significant abnormal returns are evidenced. Given these findings, the study cannot reject $\mathrm{H}_{01}$. This means that there are no significant abnormal returns either in the period before or after the event.

As the AirAsia plane crash is not an anticipated event, we might agree to the findings reported for the period before the event, where they are not related with the event, as the mean abnormal returns tend to be positive. However, we expect that the market will react negatively to the event. Positive significant abnormal returns were found on day five $(+5)$ after the event. Negative abnormal returns were documented on the day plus two (+2) plus three (+3), but the average abnormal returns are not significant.

A close examination on the trading days of the Kuala Lumpur stock exchange maybe the cause of these insignificant findings. When we look at the trading days of the Kuala Lumpur stock exchange surrounding the event, we find that the trading days are December 29, 30, 31 of 2014 and January, 02, and 04 of 2015. On January 01 (New Year holiday) and 03 (Prophet Muhammad's birthday holiday) the exchange was closed. We are unable to speculate that the behavior of stock returns reported in this study is affected by the trading days in the exchange. In other words, is it because the holidays surrounding the event that make the market participants do not overreact to the period after the event or the industry itself is not anticipating the crash?
Table 5. Results of Abnormal Returns Tests

\begin{tabular}{|c|c|c|c|c|}
\hline Period & $\begin{array}{c}\text { Mean } \\
\text { (Median) }\end{array}$ & $\begin{array}{c}\text { t-test for } \\
\text { mean } \\
\text { (p-value) }\end{array}$ & $\begin{array}{c}\text { Z-test for } \\
\text { median } \\
\text { (p-value) }\end{array}$ & Conclusion \\
\hline \multicolumn{5}{|c|}{ Panel A. Days before the event } \\
\hline-5 & $\begin{array}{c}-0.0209 \\
(-0.0066)\end{array}$ & $\begin{array}{l}-1.792 \\
(0.095)\end{array}$ & $\begin{array}{c}-0.012 \\
(0.031)^{*}\end{array}$ & Accept $\mathrm{H}_{\mathrm{a}}$ \\
\hline-4 & $\begin{array}{c}0.0135 \\
(0.0000)\end{array}$ & $\begin{array}{c}0.946 \\
(0.360)\end{array}$ & $\begin{array}{c}0.001 \\
(0.610)\end{array}$ & Reject $\mathrm{H}_{\mathrm{a}}$ \\
\hline-3 & $\begin{array}{l}-0.0112 \\
(0.0000)\end{array}$ & $\begin{array}{l}-1.565 \\
(0.140)\end{array}$ & $\begin{array}{l}-0.002 \\
(0.529)\end{array}$ & Reject $\mathrm{H}_{\mathrm{a}}$ \\
\hline-2 & $\begin{array}{c}0.0001 \\
(0.0000)\end{array}$ & $\begin{array}{c}0.009 \\
(0.993)\end{array}$ & $\begin{array}{l}-0.002 \\
(0.944)\end{array}$ & Reject $\mathrm{H}_{\mathrm{a}}$ \\
\hline-1 & $\begin{array}{l}-0.0074 \\
(0.000)\end{array}$ & $\begin{array}{l}-0.051 \\
(0.960)\end{array}$ & $\begin{array}{c}-0.005 \\
(0.563)\end{array}$ & Reject $\mathrm{H}_{\mathrm{a}}$ \\
\hline$-5--1$ & $\begin{array}{c}-0.0038 \\
(0.0000) \\
\end{array}$ & $\begin{array}{l}-0.712 \\
(0.479) \\
\end{array}$ & $\begin{array}{c}-0.003 \\
(0.112) \\
\end{array}$ & Reject $\mathrm{H}_{\mathrm{a}}$ \\
\hline \multicolumn{5}{|c|}{ Panel B. Days after the event } \\
\hline+1 & $\begin{array}{c}0.0002 \\
(0.0000)\end{array}$ & $\begin{array}{c}0.032 \\
(0.975)\end{array}$ & $\begin{array}{c}0.001 \\
(0.944)\end{array}$ & Reject $\mathrm{H}_{\mathrm{a}}$ \\
\hline+2 & $\begin{array}{c}-0.0043 \\
(0.0003)\end{array}$ & $\begin{array}{c}-0.500 \\
(0.625)\end{array}$ & $\begin{array}{l}0.0002 \\
(1.000)\end{array}$ & Reject $\mathrm{H}_{\mathrm{a}}$ \\
\hline+3 & $\begin{array}{c}-0.0155 \\
(-0.0044)\end{array}$ & $\begin{array}{l}-1.605 \\
(0.131)\end{array}$ & $\begin{array}{c}-0.008 \\
(0.235)\end{array}$ & Reject $\mathrm{H}_{\mathrm{a}}$ \\
\hline+4 & $\begin{array}{c}0.0297 \\
(0.0034)\end{array}$ & $\begin{array}{c}1.304 \\
(0.213)\end{array}$ & $\begin{array}{c}0.005 \\
(0.142)\end{array}$ & Reject $\mathrm{H}_{\mathrm{a}}$ \\
\hline+5 & $\begin{array}{c}0.0093 \\
(0.0056)\end{array}$ & $\begin{array}{c}2.547 \\
(0.023)^{*}\end{array}$ & $\begin{array}{c}0.008 \\
(0.017)\end{array}$ & Reject $\mathrm{H}_{\mathrm{a}}$ \\
\hline $\begin{array}{c}+1- \\
+5\end{array}$ & $\begin{array}{c}0.0038 \\
(0.0023) \\
\end{array}$ & $\begin{array}{c}0.686 \\
(0.495) \\
\end{array}$ & $\begin{array}{c}0.002 \\
(0.306)\end{array}$ & Reject $\mathrm{H}_{\mathrm{a}}$ \\
\hline
\end{tabular}

Note:

Bold typed numbers indicate the test used for testing hypotheses given the distribution of data. * indicates significant at $5 \%$ level

As the distribution of the data is not normal, both before and after the event, therefore, the statistical test is based on Wilcoxon two samples test for the median. Results of Wilcoxon test are presented in Table 6. The table provides the results of both the abnormal returns and the trading volume activity. The table shows that hypothesis three $\left(\mathrm{H}_{3}\right)$ is accepted at traditional level $(\mathrm{Z}=-1.340$; $p=0.090$ ) meaning that there is the difference of abnormal returns between before and after the AirAsia plane crash. The median value of abnormal returns from days minus five (-5) to minus one $(-1)$ is 0.0000 and a median value of abnormal returns from days plus one $(+1)$ to plus five $(+5)$ is 0.0023 . The finding suggests that statistically, the abnormal returns after the crash is higher compared to the abnormal returns before the crash which may lead us to assert that after the crash abnormal returns tend to be positive.

Given the distribution of data is not normal, the appropriate test to examine the possible difference between before and after the event is non-parametric test, in this case the Wilcoxon pair test is used. Tests on the median difference of 
trading volume activities between before and after the crash shows that there is no significant different $(Z=-0.655 ; p=0.257)$. This finding asserts that the proposed hypothesis of the existence of the difference in trading volume activity between before and after the crash cannot be accepted. The increase in Trading Volume Activity days after the accident is not a warranty that the market reacts significantly by trading the stocks more. In other words, there is no trading volume activity difference in the period after the crash compared to the period before the crash.

Table 6. Results of Wilcoxon Pair Samples Test

\begin{tabular}{|c|c|c|c|c|c|}
\hline Description & Median & $\begin{array}{c}\text { Median } \\
\text { Different }\end{array}$ & $\mathrm{Z}_{\text {Stat }}$ & $\mathrm{p}$ & Conclusion \\
\hline $\begin{array}{l}\text { AR Before } \\
\text { AR After }\end{array}$ & $\begin{array}{l}0.0000 \\
0.0023\end{array}$ & 0.0023 & -1.340 & $0.090^{*}$ & Accept $\mathrm{H}_{\mathrm{a}}$ \\
\hline $\begin{array}{l}\text { TVA Before } \\
\text { TVA After }\end{array}$ & $\begin{array}{l}0.0016 \\
0,0026\end{array}$ & 0.001 & -0.655 & 0.257 & Reject $\mathrm{H}_{\mathrm{a}}$ \\
\hline
\end{tabular}

Overall, the findings of this study do not show consistent and significant abnormal returns on the days after the crash of AirAsia plane of the stocks in the travel and leisure industry. The findings reported here is in contrast to [4], [10], and [8] who report negative reaction after the crash. However, it seems that the findings of this study are in support to those of [1] and [3] who do not find significant negative reaction on days after the crash.

Without trying to speculate, we might argue that the findings reported in this study may be profoundly affected by the market trading condition surrounding the event. As mentioned before, the study uses the event of AirAsia plane crash that occurred on 28 December 2014. The Kuala Lumpur stock exchange was about to have two public holidays, the New Year of 2015 and the Prophet Muhammad's birthday (January 03, 2015). These holidays coupled with the New Year effect, where some the market participants may still have their holiday, have made the impact of the airplane crash may not material.

\section{CONCLUSION}

This study examines whether the AirAsia plane crash of 28 December 2014 affects the value of stock in the travel and leisure industry listed at the Malaysian stock market. Investigating 15 companies and using five days windows, the study does not find the existence of abnormal returns on days surrounding the event. Abnormal returns were identified on day five before the event and day five after the event. Another finding reveals that there is abnormal returns difference between before and after the event. Examination of the trading volume activity shows that no significant different between before and after the event. Overall, we come to conclude that the AirAsia plane crash does not lead abnormal returns on the stock prices in the travel and leisure industry.

Two limitations are identified in the study. This study does not consider the effect of the end of year trading activity. We might argue that the holidays around the event days may have affected the trading strategy of the investors. So, the future study may take into account the possibility of the end of year effect on the stock market. This study does not consider the possibility of other events during the windows of analysis. Accordingly, the future research may take into account other surrounding events that may become the confounding effect.

\section{REFERENCES}

[1] Chance, D.M. and Ferris, S.P. (1987). The effect of aviation disasters on the air transport industry: A financial market perspective. Journal of Transport Economics and Policy, 21(2), 151-165.

[2] Chandra, A. and Memarista. (2014). Perbedaan average abnormal return, average trading volume activity sebelum dan sesudah pemilu di Indonesia. Jurnal Fiesta, 2 (1), 114-118.

[3] Costa, M.R., Galdi, F.C. and Nossa, S.N. (2013). Investment strategy based on aviation accidents: Are there abnormal returns?. Journal of Education and Research in Accounting. 7(2), 177-190

[4] Davidson III, W.N., Chandy, P.R. and Cross, M. (1987). Large losses, risk management and stock returns in the airline industry. Journal of Risk and Insurance, 54(1), 162-172.

[5] Demir, E. (2015). Aviation accidents and stock market reaction: Evidence from Borsa Istanbul. Eurasian Journal of Economics and Finance, 3(1), 51-56.

[6] Gumanti, T.A., Lestari, A.R. and Puspitasari, N. (2015). Central bank announcements on interest rate changes and stock prices of Indonesian banking industry. Investment Management and Financial Innovations, 12(3), 87-92.

[7] Hiemstra, C. and Jones, J.D. (1994). Testing for linear and nonlinear Granger causality in the stock price volumes relation. Journal of Finance, 49(5), 1639-1664.

[8] Ho, J.C., Qiu, M. and Tang, X. (2013). Do airlines always suffer from crashes?. Economics Letters, 118(1), 113-117. 
[9] Kaplanski, G. and Levy, H. (2010). Sentiment and stock prices: The case of aviation disasters. Journal of Financial Economics. 95(2), 174-201

[10] Lin, M.Y., Thiengtham, D.J. and Walker, T.J. (2005). On the performance of airlines and airplane manufacturers following aviation disasters. Canadian Journal of Administrative Sciences, 22(1), 21-34.

[11] MacKinlay, A.C. (1997). Event studies in economics and finance. Journal of Economics Literature, 35(1), 13-39.

[12] Manurung, A.H., and Cahyanti. (2007). Pengaruh peristiwa politik terhadap transaksi saham di Bursa Efek Jakarta. Jurnal Bisnis \& Manajemen, 7(2), 135-146.

[13] McGowan, Jr., C.B., and Jakob, N. A. (2010). Is there an Eid al-Fitr Effect in Malaysia?. International Business \& Economics Research Journal, 9(4), 11-20.

[14] McWilliams, A., and Siegel, D. (1997). Event studies in management: Theoretical and empirical issues. Academy of Management Journal, 40(3), 626-657.
[15] Prabhala, N.R. (1997). Conditional methods in event studies and equilibrium justification for standard event-study procedures. Review of Financial Studies, 10(1), 1-38.

[16] Rahardian, L. (2015). Setahun terakhir empat kecelakaan terjadi di Indonesia. CNN Indonesia. http://www.cnnindonesia.com/nasional/ 20151002221633-20-82511/setahun-terakhirempat-kecelakaan-udara-terjadi-di-indonesia/.[10 Februari 2016].

[17] Ratner, M., and Leal, R.P.C. (2001). Stock returns and trading volume: Evidence from the emerging markets of Latin America and Asia. Journal of Emerging Markets, 6(1), 5-22.

[18] Ryan, P., and Taffler, R.J. (2004). Are economically significant stock returns and trading volumes driven by firm-specific news releases?. Journal of Business Finance \& Accounting, 31(1\&2), 49-82

[19] Shafa, S. (2014). Kecelakaan tragis pesawat sepanjang tahun 2014. Detik Travel. http:// travel.detik.com/read/2014/07/18/132830/264117 4/1382/4/3-kecelakaan-tragis-pesawat-sepanjang-tahun-2014\#menu_stop. [18 Juli 2016].

Appendix: Firms Examined in the Study

\begin{tabular}{cllcl}
\hline No. & \multicolumn{1}{c}{ Name of Firm } & Stock Name & Stock Code & Sector \\
\hline 1. & AirAsia X Bhd & AAX & 5238 & Consumer Service \\
2. & AirAsia Bhd & AIRASIA & 5099 & Consumer Service \\
3. & Advance Synergy Bhd & ASB & 1481 & Consumer Service \\
4. & Berjaya Food Bhd & BJFOOD & 5196 & Consumer Service \\
5. & Borneo Oil Bhd & BORNOIL & 7036 & Consumer Service \\
6. & Genting Malaysia Bhd & GENM & 4715 & Consumer Service \\
7. & Genting Bhd & GENTING & 3182 & Consumer Service \\
8. & Konsortium Transnasional Bhd & KTB & 4847 & Consumer Service \\
9. Landmarks Bhd & LANDMRK & 1643 & Hotels \\
10. Magnum Bhd & MAGNUM & 3859 & Consumer Service \\
11. & Mulpha Internasional Bhd & MULPHA & 3905 & Consumer Service \\
12. & Olympia Industries Bhd & OLYMPIA & 3018 & Consumer Service \\
13. & Only World Group Bhd & OWG & 5260 & Consumer Service \\
14. & Pan Malaysia Holdings Bhd & PMHLDG & 1287 & Hotels \\
15. & RGB International Bhd & RGB & 0037 & Consumer Service \\
\hline
\end{tabular}

